\title{
Policy Issues in the Administration of Higher Education in Nigeria
}

\author{
Ogbogu Christiana, O.,** \\ ${ }^{1}$ Department of Public Administration, Faculty of Administration, Obafemi Awolowo University, Ile-Ife, Osun State, \\ Nigeria \\ *Correspondence: Department of Public Administration, Faculty of Administration, Obafemi Awolowo University, \\ Ile-Ife, Osun State, Nigeria Tel: 234-803-426-665-522Ｅ-mail: tinaogbogu@yahoo.com
}

Received: November 15, $2012 \quad$ Accepted: January 2, $2013 \quad$ Online Published: January 17, 2013

doi:10.5430/wje.v3n1p32

URL: http://dx.doi.org/10.5430/wje.v3n1p32

\begin{abstract}
This paper evaluates policy initiatives in the Nigerian higher educational system with a view to bringing it in line with good practices. Issues of gender, management/governance, teaching, research and funding were discussed. The study revealed that government's funding is insufficient to maintain institutional performance because of the policy stance of non-payment of tuition fees at undergraduate level. It advocates policy reforms that support cost sharing with students but with appropriate mix of scholarships to enable students pay prescribed fees. The paper indicated that participatory governance is appropriate in administering universities because of its capacity to involve relevant stakeholders in decision-making. The paper highlighted that, teaching and research in Nigerian Universities are not responsive to employers' requirements; and new policy initiatives geared towards ameliorating the situation are hampered by shortage of staff, inadequate funding and poor physical facilities. The paper found that gender inequality in higher education is a social problem which has necessitated the creation of centres for mainstreaming gender in the system. The study concluded that for Universities and other higher educational institutions in Nigeria to remain self-reliant, self-steering and able to survive in a competitive world; various higher education policies should be effectively institutionalized and operationalised.
\end{abstract}

Keywords: higher education; university; educational policies; administration; Nigeria

\section{Introduction}

Higher educational institutions are recognized all over the world as centres of excellence where knowledge is not only acquired but also disseminated to those who require it, through teaching and research. Orlans and Smith (1992) posited that higher educational institutions are the summit where everything that happens directly comes together and where learning in the deepest sense of the word is cultivated. Clark (1987) drawing on a nostalgic memory of the nineteenth-century Oxford asserted that the function of universities is to produce 'a culture of the intellect' and train the leaders of society to have 'the force, the steadiness, the comprehensiveness, the versatility of intellect and the command over powers'. Knowledge has become the most important factor for economic development in the $21^{\text {st }}$ century and it constitutes the foundation of a country's competitive advantage because of its capacity to augment productivity (World Bank, 1999). Higher educational institutions are therefore instruments for advancing such knowledge by developing high level technical capacity that underpin economic growth and development.

The administration of higher educational institutions refers to the means by which higher educational institutions are operated, organized and managed. Bleiklie (2007) asserted that the administration of higher educational institutions deals with how higher educational institutions steer themselves as well as the process used to manage them in such a way as to lead to effective performance in achieving desired outcomes, goals and satisfaction of stakeholders. Becher and Kogan (1992) posited that administration of higher educational institutions is concerned with the determination of values inside universities, their systems of decision-making and resource allocation, their mission and purpose, the patterns of authority and hierarchies and the relationship of universities as institutions to the different academic worlds. The administration of Nigerian higher educational institutions is legally provided for in their Acts and Statutes; and the government is expected to provide the enabling policy and legal frameworks for them to function (Okebukola, 2006). University administration for instance revolves around the Vice-Chancellor who is both the academic and administrative head of the institution. He is supported by one or sometimes two deputy 
Vice-Chancellors and a number of senior academic staff such as Provosts/Deans of Colleges, Faculties/Schools and Heads of Departments, (Erero, 1996). In addition to this, the Registrar, the Bursar, the Librarian as well as an array of other administrative staff assist the Vice-Chancellor in managing the affairs of the University. Academic and administrative activities are carried out through committees of Council and Senate. Universities are particularly complex institutions and the decisions and choices which they make also become more complex as the requirements of students, staff, employer and the society change. All of these place a premium on good policies (Adamolekun, 2007).

Policies are not only essential for effective institutional management, but also for ensuring sustainability of all the systems and institutional transformation (Akilagpa, 1992). Policy issues in the administration of higher educational institutions in Nigeria are embedded in the National policy on Education. The policies are geared towards ensuring that the goals of higher educational institutions are achieved. Furthermore, policies in higher educational institutions define roles and responsibilities of individuals in management and define targets for units, departments and faculties in order to improve teaching and learning. They also define effective and transparent criteria and processes for the appointment, promotion and reward of staff (Abdulrahman and Ogbaondah, 2007).

However, many developing countries including Nigeria have not been able to articulate such policy strategies due to numerous challenges. According to Ogbogu (2011), these challenges include rising student numbers without commensurate increase in funds, problem of poor management, gender inequality, poor teaching and research facilities, etc. In order to respond to these problems and bring the country's higher educational system in line with international good practices, the Nigerian government initiated certain policies. 'The University Hostel Development and Management Initiative' is an example of one of such policies which was intended to guide the administration of Universities in providing a conducive environment for learning, (Okebukola, 2002). The policy was also to enable Universities channel more resources towards teaching, learning and research as well as reposition them in line with global higher education practice. Another major policy initiative on funding was the separation of the costs of academic activities from the regular overhead costs (for goods and services) through the creation of a separate Direct Teaching and Laboratory Cost (DTLC) budget in 2004. This was meant to guarantee the funding of the day-to-day academic activities in federal universities at departmental level (Okebukola, 2006). The various initiated policies were intended to create a more flexible and responsive system of University administration and also enhance the teaching and research activities, that over time will contribute increasingly to national innovation capacities, productivity gains and economic growth.

This paper therefore, reviews policy issues in the administration of higher educational institutions, with particular reference to the University system which is the apex of all other higher educational institutions in Nigeria.

\section{Funding}

Finance is a major driver in actualizing the various policies of Universities as well as in ensuring their smooth administration. In Nigeria the policy document on financing of higher education specifies that since education is an expensive social service, it requires adequate financial provision from government for the successful implementation of the various programmes (FGN, 2004). Aina (2007) noted that government provides about 90 percent of the funds required for the administration of Universities and welcomes individuals, other organizations as well as individual Universities in providing the remaining 10 percent. Saint, Hartnett and Strassner (2003), observed that in practice, government is unable to adequately fund the University system and the current funding strategy does not serve the country's long term development interests. Consequently, funding short falls have been the norm for many years as enrollments have increased more quickly than the government's capacity to maintain its proportional financial support. In view of this, Ogbogu (2011) posited that gross under funding undermines University autonomy in Nigeria and that the financial crisis has also generated an obvious deterioration in the quality of education. Okebukola (2006) indicated that because of the education budget cuts, quality of education is seriously affected by the deterioration and scarcity of facilities and equipment such as laboratories, libraries and general teaching materials. These constraints have been mainly the result of government's insistence on being the major source of financial support for institutions of higher learning. Thus Adedeji (2002) posited that the existing policy stance of government against levying tuition fees at undergraduate level in Federal Universities might have to change, because government's funds have become insufficient to maintain institutional performance in teaching, research and administration. This is evident in grossly inadequate budget allocations for recurrent, capital and research expenditures. Universities elsewhere in the world have sought to supplement their public funding with locally generated income most especially from tuition fees, cost - recovery business income, investment income, gifts, philanthropy etc (Johnstone, 2003). The principal untapped 
source of University financing in Nigeria remains undergraduate students' tuition fees, which is the most University's recurrent budget around the world (Hartnett, 2000).

However, Nigerian government's policy approach with regard to tuition charges has been cautious and carefully conditioned. This is because cost - sharing with students remains highly contentious within the country's fragile democratic environment. The government's stand is that before fees can be re-introduced or charges increased, the students and their sponsors must be economically empowered to be able to pay such fees and charges. Adamolekun (2007) therefore opined that policy reform in this direction would need to be accompanied with appropriate mix of scholarships and loans that would ensure that no Nigerian who is qualified for University education is denied the opportunity because of his/her inability to pay prescribed fees. In view of this, Okebukola (2006) suggested that more creative financing strategies are needed in order for Nigerian Universities to offset the likely risks of declining educational quality, resource efficiency and learning effectiveness that currently confront it (Saint, Hartnett and Strassner, 2003). The danger in this is that the teaching and research mission of Universities would drop in priority and would become distorted because of the search for entrepreneurial revenue.

\section{Management and Governance}

Universities in most parts of the developed world lay emphasis on shared governance. This policy maintains that faculty involvement in University governance is critical. It defines management styles in terms of vested partnership between faculty and administration (Bleiklie, 2005). This implies a collaborative partnership whereby faculty is involved in the decision making process that affect them. These include: personnel decisions, salary decisions, preparation of budget, determination of educational policies, etc. Gornitzka et al (2005) added that the policy emphasizes re-balancing of University administration to reflect the changing roles in human resources. Furthermore, the policy emphasizes that State and Federal Government and external agencies should refrain from intervening in the internal governance of higher institutions. It recognizes the fact that conserving the autonomy of higher educational institutions is essential to protecting academic freedom, the advancement of knowledge and the pursuit of truth (Ogbogu, 2011). In furtherance of this, Adamolekun (2007) affirmed that shared governance is the deliberate inclusion of persons or groups within the University community in consultative meetings, in decision making, in implementation or in a combination of these. He indicated that shared governance in Nigerian Universities would be an appropriate approach in the realm of academic administration where Provosts/Deans of Colleges/Schools/ Faculties and Heads of Departments/Institutes have direct responsibility for the quality of teaching and research for which the Senate, presided over by the Vice-Chancellor, sets broad directions and pronounces the results of examinations. Regarding the administrative realm, Adamolekun (2007) indicated that although team work is appropriate, the final authority and accountability lie on the Vice-Chancellor. He however noted that a leadership style that seeks to involve relevant stakeholders within the university community in respect of specific tasks is the most conducive to the achievement of intended outputs and outcomes.

Aina (2007) posited that in Nigeria, responsibility for institutional policy making and decisions resides with a University Council whose membership is normally drawn from government, the University and organizations from the private sector. Academic affairs are managed by the University Senate which possesses full responsibility for this. According to Clark (2001) this feature of the university is its relatively fragmented organizational structure which is run through committee systems. In Nigeria, there are administrative policies which define the responsibilities of university administration including legal obligations and legislative requirements for the governing boards. They ensure that all staff members are aware of the nature of their duties and responsibilities. In Obafemi Awolowo University for example, the central administrative management department is the directorate of personnel affairs. The directorate is divided into four sections via:-

(a) Junior staff establishment (JSE)

(b) Administrative and technical staff establishment (ATSE)

(c) Academic staff establishment (ACSE) and

(d) Staff training and development unit (STD).

It is within these units that Provosts, Deans, Heads of Departments / Units have to deal with the performance of their personnel management functions such as issues related to appointments, leave, promotion, regrading, training, discipline etc (Erero, 2008) 
Recognizing the importance of the concept of shared governance and re-balancing of University governance in Nigeria, Okebukola (2002) confirmed that the National Universities Commission (NUC) took steps in 2001 to promote more professional institutional management by encouraging institutional strategic planning (an instrument of participatory governance and institution renewal). It organized annual management training workshops for senior administrators and established a uniform accounting code for the University system. Although the National Universities Commission (NUC) is doing a good job, the Academic Staff Union of Universities (ASUU) is of the view that it is usurping the legitimate functions of the Senate and is involved in many activities that derogate from the functions of University authorities. This implies that its centralized and unified approach stifles experimentation and initiative at the level of individual Universities (Erero, 2008).

The emergence of a more responsive University management is slow. Clark (2001) attributes this to the limits on government funding capability combined with rigid internal organizational structures. Currently, University administration is based on participatory system of Senate and various committees, but their agendas and practices are increasingly old fashioned. Therefore, there is need for a strategic reorientation of these bodies in response to changing national circumstances. This lack of adaptability in the light of changing circumstances may hinder Nigerian Universities from competing effectively in an increasingly competitive and globalizing world (Ogbogu, 2011)

\section{Teaching and Research}

Orlans and Smith (1992) opined that teaching and research based on independent inquiry and which is conducted by a group of scholars lies in the heart of Universities. They are the ingredients required by universities to maintain their standing as centres of fundamental thinking and intellectual leadership that will ensure that they remain a force in the $21^{\text {st }}$ century. It is widely accepted that teaching and research are the most important sources of knowledge generation and they play key roles in promoting sustainable development. Research particularly helps solve practical problems and brings about material improvements via high - tech products. It also provides insights and new ideas that enrich human understanding of various social, economic and cultural phenomena (Abbort and Dencouliagos, 2004).Thus, promotion of sustainable development through teaching and research should be integral policy issues in higher educational institutions in Nigeria. In order to achieve this, Clark (2001) suggested that Universities should review their curricular on a regular basis in order to ensure that the content of their teaching reflects the rapidly advancing frontiers of scientific knowledge.

In Nigeria, greater attention to innovation in both curricular and pedagogy is poor. This is evident in the high drop out rate of students from the Universities as well as the poor quality of University graduates. Dabalen, Oni and Adekola (2000) affirm that University graduates are poorly trained and the shortcomings are severe in oral and written communication and in applied technical skills. They added that the supply of education services is not market sensitive and admission policies are not related to labour demand requirement. In developed countries, institutions adapt to the problem of labour market mismatch by forming knowledge coalitions with other knowledge producing centers in the societies. In addition to this the government establishes more effective labour market information systems linked to career counseling in universities and greater private sector involvement in curriculum consultations, faculty attachment, student placements and research funding. Erero (1996) however noted that the factors responsible for the poor quality of teaching and research activities in Nigerian Universities include strikes, poor teaching and research facilities, inconsistent funding efforts of government, teacher shortages, etc.

In response to the various constraints to effective teaching and research, government came up with series of policies. For example, Oyebamiji (2005) posited that the government reconstituted all university councils to incorporate broad stake holder representation in the council and accorded greater autonomy to University Councils and managers in the effort to promote institutional responsiveness. It adopted a formula based resource allocation procedure in disbursing grants that facilitate strategic planning. Furthermore, government has returned to university Senates the power (Previously held by the NUC) to determine curricular and to initiate or terminate courses. It has established reference points for quality improvements and has developed academic benchmarks based on competencies. Government statement also promotes the need for Universities to partner with the private sector (Federal ministry of education, 2002) in order to advance research.

These policy initiatives geared towards enhancing educational quality and administration of Universities are hampered by shortage of staff within the University system, rising workloads associated with deteriorating staff/student ratios, inadequate funding and poor state of physical facilities. 
In today's world, the content and method of Nigerian Universities' teaching and research is weak and not responsive to employers' requirements. Its research output is low and unable to prompt innovation - based productive gains. Table 1 below summarizes it all. The Table shows Nigerian Universities in Africa and world rankings. It should be noted that cross - country comparison of University performance constitutes a yardstick for measuring the performance of each Nigerian University and the entire national university system. Based on the current rankings of Nigerian Universities, it would take about five to ten years before two or three of them can realistically join the ranks of the world's top 1000 Universities (Adamolekun, 2007).

Table 1: Nigerian Universities in Africa and World Rankings

\begin{tabular}{lll}
\hline Universities & World Ranking & African ranking \\
\hline University of Ibadan & 6,304 & 57 \\
Obafemi Awolowo University & 6,645 & 69 \\
University of Benin & 6,769 & 78 \\
University of Lagos & 7,181 & 90 \\
University of Jos & 7,369 & 98 \\
\hline
\end{tabular}

Source: Adapted from Adamolekun (2007): Challenges of University Governance in Nigeria: Reflections of an Old Fogey.

\section{Gender Issues}

Gender inequality in Nigerian higher educational institutions mirrors that in the larger society. Its ability to interfere with the quality of female academics, administrators and students' experiences and achievements has been recognized as a social problem. Existing data and literature show that women are not proportionately represented in the student and staff categories in Nigerian Universities. Currently offering service in Nigerian universities are 20, 214 academic staff, out of which 3,174 (15.7\%) are females and 17,040 (84.3\%) are males. Female professors make up 6.9 percent of the professorial college and over 70 percent of them are in the humanities. There are about 64,506 non-academic staff in Nigerian Federal universities out of which about 45 percent of them are females (Ogbogu, 2009).

In Nigeria, concern for gender equity has become a policy issue in higher educational institutions and some have started to address it. Some Universities now have centres for gender studies, an instrument through which gender can be mainstreamed in University Administration. Ogbogu (2010) and Abiose (2008) indicated that Obafemi Awolowo University which is one of the first generation Universities in Nigeria recognizes that its journey into the $21^{\text {st }}$ century can only be accelerated by building a congenial learning environment where the talents of men and women are equitably harnessed. In response to the observed gender disparities, the Obafemi Awolowo University in conjunction with Carnegie Corporation in the "Gender Equity project" implemented various intervention programmes such as: scholarships and fellowships for female students and staff respectively, sensitization and advocacy workshops, enlightenment and outreach programmes as well as networking with other Universities within and outside Nigeria.

Recently, the Centre for Gender and Social Policy Studies developed a Gender Policy for the University. The Policy is an instrument for institutionalizing gender equity in every aspect of University life. The overall goal of the Policy is to promote gender equity within the University system in order to guarantee organizational effectiveness, fundamental human rights and equity. This achievement has placed the University in its rightful position as one of the leading gender equitable institutions in Nigeria (Abiose, 2008).

\section{Conclusion}

In recognition of the need to foster and strengthen higher education system in Nigeria and to bring them more in line with global good practices, new higher education policies have been initiated in recent times. This initiative is timely because of the dimension of the challenges which confront universities and which severely affect their efficient administration. The policies respond to the long-festering problems of governance and management, financing, access and quality. For Nigerian Universities to compete effectively in an increasingly competitive world there is constant need to secure greater value from available resources. Policy issues also need to be addressed and the various policies should be effectively institutionalized and operationalized. For instance, the National Universities 
Commission introduced policies that promote the efficient allocation and utilization of funds to academic and research activities in each Nigerian University. The policies ensured that research grants accounted for at least 5 percent of total recurrent expenditure, while at least 60percent of the total recurrent grants were allocated to direct teaching units. In order to promote more efficient University management and governance, the Commission institutionalized strategic planning and it currently regularly organizes workshops for top University managers. In addition, the Commission and UNESCO regularly organize conferences and roundtable discussions with Universities on the future directions of higher education and policy initiatives introduced by government. These initiatives are geared towards enhancing the efficient administration of Universities. The success of the policies and initiatives is likely to depend upon the extent to which the present rigidities with the National Universities Commission (NUC), the University Staff Unions and within the Universities themselves can be replaced by more flexible and responsive practices. Also, the principle task is to institutionalize and operationalize the policy initiatives effectively. In order for this to occur, greater flexibility and responsiveness as well as an enabling environment should be created by both the Government and the University system for the emergence of progressive, self-steering, self-regulating and self-reliant Universities in Nigeria.

\section{References}

Abbort, O., \& Doucouliagos, P. (2004). Research output of Australian Universities. Education Economics, 12(3), 251-265. http://dx.doi.org/10.1080/0964529042000258608

Abdulrahman, Y.M., \& Ogbaondah, L. (2007). Policy nurturing and puncturing in the Nigerian educational reforms and implementation. African Journal for Contemporary issues in Education, 1, 112-120.

Adedeji, S. (2002). The cost and financing of education in Nigeria: The historical perspective. A paper presented at the forum on cost and financing of education in Nigeria. Education Sector Analysis (ESA): Abuja, Nigeria.

Abiose, S.H. (2008). Gender Policy for Obafemi Awolowo University. OAU-Carnegie Gender Equity Initiative Bulletin, 6(1), 2-3.

Adamolekun, D. (2007). Challenges of University Governance in Nigeria: Reflections of an Old Fogey. Convocation Lecture, Adekunle Ajasin University, Akungba, Ondo State. February 22, 2007.

Aina, O.I. (2007). Alternative modes of financing Higher education in Nigeria and implications for university governance. In Babalola , J.B. and Emunemu B.O. (Eds.)Issues in higher education: Research evidence from sub-Saharan African. Lagos: Bolabay Publications.

Akilagpa, S. (1992). Relations between Government and University in Ghana: A case Study. In G. Neave and F.Van Vught, F. (Eds.) Government and higher education relations across three continents: The winds of change. Oxford: Pergamon.

Becher, T., \& Kogan, M. (1992). Process and structure in higher education. Milton Keynes: Open University Press.

Bleiklie, I. (2005). Academic leadership and emerging knowledge regimes. In Bleiklie, I and Henkel, M (Eds.) Governing Knowledge: A study of continuity and change in higher education. Dordrecht: Springer.

Bleiklie, I. (2007). Systemic integration and macro steering. Higher Education Policy, 20, 391-412. http://dx.doi.org/10.1057/palgrave.hep.8300166

Clark, B. (2001). The entrepreneurial University: New foundations for collegiality, Autonomy and achievement. Higher Education Management, 13(2), 9-24.

Dabalen, A., Oni, B., \& Adekola, O. (2000). Labour market prospects for University graduates in Nigeria. Higher Education Policy, 14, 141-159. http://dx.doi.org/10.1016/S0952-8733(01)00010-1

Erero, E.J. (1996). Towards the Nigerian University of the $21^{\text {st }}$ century: Challenges and opportunities. In T. Omole and I. Nassar (Eds.) Nigerian Administration and beyond the year 2000 AD: Challenges and opportunities. Lagos: Strategic International Press.

Erero, E.J. (2008). Human resource management and personnel functions in Obafemi Awolowo University, Ile-Ife. Paper presented at a workshop for Principal Administrative and Academic Staff of Obafemi Awolowo University, Ile-Ife, Osun State.

Federal Ministry of Education (2002). Communiqué: National Summit on Higher Education, March 11-16. Abuja, Nigeria. 
Federal Government of Nigeria (2004). National Policy on Education. Lagos.

Gornitzka, A., Kogan, M., \& Amaral, A. (2005). Reform and change in higher education: Analyzing policy implementation. Dordrecht: Springer. http://dx.doi.org/10.1007/1-4020-3411-3

Hartnett, T. (2000). Financing trends and expenditure patterns in Nigerian Federal Universities: An update unpublished report. Washington D.C. World Bank.

Johnstone, O.B. (2003). Cost sharing in higher education: Tuition, financial assistance and accessibility. Czech Sociological Review, 39(3), 351-374.

Ogbogu, C.O. (2009). An analysis of female research productivity in Nigerian Universities. Journal of Higher Education Policy and Management, 31(1), 17-22. http://dx.doi.org/10.1080/13600800802558841

Ogbogu, C.O. (2010). Gender factors affecting female labour input in the Nigerian University System. Gender and Behavior, 8(1), 2666-2677.

Ogbogu, C.O. (2011). Modes of funding Nigerian Universities and the implications on performance. Paper presented at the 2011 Barcelona European Academic Conference, Barcelona, $6^{\text {th }}-9^{\text {th }}$ July.

Okebukola, P.A. (2002). The state of university education in Nigeria. Abuja: National Universities Commission.

Okebukola, P. (2006). Principles Guiding Current Reforms in Nigerian Universities. Journal of Higher Educational Administration, 4(1), 25-36.

Orlans, H., \& Smith, B.L. (1992). Minerva: A Review of Science, Learning and Policy, 30(2), 132-13

Oyebamiji, M.A. (2005). Community education and leadership development in Nigeria. Journal of Educational focus, 6(30), 13-24.

Saint, W., Hartnett, T., \& Strassner, E. (2003). Higher Education in Nigeria: A status report. Higher Education Policy, 16, 259-281. http://dx.doi.org/10.1057/palgrave.hep.8300021

World Bank. (1999). World development report: Knowledge development report. Washington, D.C: The World Bank. 